\title{
Strategic priorities of cooperation between Heilongjiang province and Russia
}

\author{
L. Song \\ Institute of Northeast Asian Studies, Heilongjiang Provincial Academy of Social Sciences, Harbin, China; \\ e-mail: songlinlin713@163.com
}

\begin{abstract}
During the five-year period of implementation of the Belt and Road Initiative, Heilongjiang Province, which is one of the nine Chinese border provinces, has actively responded to the national development policy and achieved some impressive results in its strategic cooperation with the Russian Far East. The article characterizes the current state of Heilongjiang Province's relationship with Russia and describes its strategic plans for findings new paths of cooperation as a result of the province's integration into the Belt and Road Initiative and participation in China-Mongolia-Russia Economic Corridor construction. The key projects crucial for the province's development are the Eastern Land-Sea Silk Road Economic Belt (hereinafter referred to as the Eastern Silk Road Belt) and the Heilongjiang Land-Sea Silk Road Economic Belt (hereinafter referred to as Longjiang Silk Road Belt). Both projects are aimed at increasing the interconnectedness between regions and countries, promoting international trade and fostering understanding and tolerance. The article describes the background, objectives, results and problems associated with these projects in Heilongjiang Province and their role in ensuring further socio-economic development of the territory. Finally, recommendations are given concerning the main areas of cooperation between the province and Russia: these include modernization of trade (e-commerce), fostering cooperation in the industrial sphere and agriculture, and opening a free cross-border trade zone.
\end{abstract}

\author{
KEYWORDS \\ Belt and Road Initiative; \\ Heilongjiang Province; Eastern \\ Silk Road Belt; Longjiang Silk \\ Road Belt; strategic planning; \\ cooperation
}

\section{ACKNOWLEDGEMENTS}

Heilongjiang Province, the special subject of the $12^{\text {th }}$ Fourth Plenary Session of "Research on the Construction of New Pattern of All-dimensional Opening up in Heilongjiang Province", project No. 18GJH786

\section{FOR CITATION}

Song, L. (2019) Strategic priorities of cooperation between Heilongjiang province and Russia. R-economy, 5(1), 13-18. doi: 10.15826/recon.2019.5.1.002

\section{Стратегические приоритеты сотрудничества между провинцией Хэйлунцзян и Россией}

\section{Л. Сонг}

Институт исследований Северо-Восточной Азии, Академия общественных наук провиниии Хэйлунизян, Харбин, Kumaŭ; e-mail: songlinlin713@163.com

\begin{abstract}
АННОТАЦИЯ
В течение пятилетнего периода реализации инициативы «Один пояс, один путь» провинция Хэйлунцзян, которая является одной из девяти приграничных провинций Китая, активно реагировала на политику национального развития и достигла некоторых значительных результатов в своем стратегическом сотрудничестве с российским Дальним Востоком. В статье дается характеристика нынешнего состояния отношений провинции Хэйлунцзян с Россией и описываются ее стратегические планы по поиску новых путей сотрудничества в рамках участия в инициативе «Один пояс, один путь». Также описано участие провинции в строительстве экономического коридора Китай-Монголия-Россия. Ключевыми проектами, имеющими значение для развития провинции, являются Экономический пояс Восточно-Шелкового пути (в дальнейшем именуемый «Восточный шелковый путь») и Экономический пояс Хайлунцзян-Шелковый путь («Лунцзянский пояс Шелкового пути»). Оба проекта направлены на улучшение связей между регионами и странами, развитие международной торговли, взаимопонимания и терпимости. В статье описываются предпосылки, цели, результаты и проблемы, связанные с этими проектами в провинции Хэйлунцзян, и их роль в обеспечении дальнейшего социально-экономического развития территории. Также в статье даны рекомендации по основным направлениям сотрудничества между провинцией Хэйлунцзян и Россией: они включают модернизацию торговли (электронная коммерция), развитие сотрудничества в промышленной сфере и сельском хозяйстве, а также открытие зоны свободной трансграничной торговли.
\end{abstract}

(c) L. Song, 2019

\section{КЛЮЧЕВЫЕ СЛОВА}

Belt and Road Initiative; Heilongjiang Province; Eastern Silk Road Belt; Longjiang Silk Road Belt; strategic planning; cooperation

\section{БЛАГОДАРНОСТИ}

Провинция Хэйлунцзян, специальная тема 12-го четвертого пленарного заседания «Исследования по построению новой модели многомерного раскрытия в провинции Хэйлунцзян», проект № 18GJH786

\section{ДЛЯ ЦИТИРОВАНИЯ}

Song, L. (2019) Strategic priorities of cooperation between Heilongjiang province and Russia. R-economy, 5(1), 13-18. doi: 10.15826/recon.2019.5.1.002 


\section{Introduction}

The Silk Road has been an important trade channel, which strengthened the political, economic and cultural ties between the East and the West. In the autumn of 2013, Chinese national leader $\mathrm{Xi}$ Jinping presented to the world a picture of "shared responsibility for the world and promoted global development", which was the vision of a joint project aimed at building the Silk Road Economic Belt and the $21^{\text {st }}$ Century Maritime Silk Road. The project is expected to help China open up to the West, build up its maritime power, promote tolerance and find new ways of developing peaceful, mutually beneficial cooperation.

Heilongjiang Province is one of China's nine border provinces, it shares $2,981 \mathrm{~km}$ of its border with Russia and has 25 first-class national ports. The province enjoys a long history of cooperation with Russia, especially in the sphere of border trade. Currently cooperation also encompasses such spheres as agriculture, forestry, mineral resources, energy, tourism, science and technology, and culture. In the past five years, Heilongjiang Province joined the national Belt and Road strategy; participated in the construction of China-Mongolia-Russia Economic Corridor; and actively implemented the comprehensive strategy of cooperation with Russia and the Russian Far East [1].

The structural framework of the paper consists of three parts. The first part describes the current situation of cooperation between Heilongjiang Province and Russia. The second part covers the construction of the Eastern Silk Road Belt, which is connected with the Belt and Road Initiative and is expected to improve the province's economic and geopolitical situation [2]. The third part deals with another major project the Longjiang Silk Road Belt.

Heilongjiang Province strives to integrate its strategy into national strategic plans and focuses on joining the Belt and Road Initiative, the provincial Five Major Plans and the $13^{\text {th }}$ Five-Year Plan [3]. The strategic priorities of Heilongjiang Province in its cooperation with Russia are related to the construction of China-Mongolia-Russia Economic Corridor and other aspects, such as cooperation in the sphere of infrastructure, energy and resources, trade, cultural exchanges and so on [4]. The province has established a new pattern of cooperation with its northern partner in line with the goals outlined by General Secretary XI JinPing in his speech made in Heilongjiang Pro- vince at the Belt and Road Forum for International Cooperation [5-8].

\section{Cooperation between Russia and Heilongjiang Province: current state}

The following table describes the changes in the total volume and growth rate of imports and exports from Heilongjiang Province to and from Russia between 2008 and 2018. The growth rate of import and export trade between Heilongjiang Province and Russia is relatively large and is growing steadily. Since 2007, Heilongjiang Province became China's first province to reach the level of US $\$ 100$ million in trade with Russia. In 2009, however, due to the financial crisis, the bilateral trade volume fell sharply. In 2011, the trade between the province and Russia started to grow again due to the operation of the Sino-Russian crude oil pipeline. In recent years, China has been one of Russia's key trading partners and the trade liberalization policy greatly facilitated and enhanced cooperation in this sphere. By mid-December 2018, Sino-Russian trade volume had exceeded 100 billion US dollars, which is a record high $^{1}$. As Table 1 illustrates, in 2018, the trade between the province and Russia was flourishing [9].

If we look at the indicators in the table above, it can be seen that in the past decade trade has been fluctuating, mainly due to the lower world energy prices. Therefore, Heilongjiang Province and Russia should come to an agreement about the new paths of cooperation that would be in line with the goals of strategic development of the two sides. The $70^{\text {th }}$ anniversary of the establishment of China-Russia diplomatic relations is to be celebrated in 2019. China-Russia bilateral economic and trade relations should take this opportunity to move to a new, higher level. It should be noted that the 2018-2019 Sino-Russian Local Cooperation and Exchange Year has also brought new opportunities for both countries. Zhang Qingwei, the Chinese chairman of the China-Russia Friendship, Peace and Development Committee, said that Heilongjiang Province would work with Russia to enhance local cooperation. Therefore, Heilongjiang Province should benefit from this opportunity to improve its relationship with Russia in various fields and to meet the strategic goals of Sino-Russian economic and trade cooperation at "the northernmost point".

Retrieved from http://www.sohu.com/a/288059706 $\underline{123753}$ 
Table 1

Statistics on the import and export of merchandise trade between Russia and Heilongjiang Province in 2008-2018, in million US dollars

\begin{tabular}{|c|c|c|c|c|c|c|c|c|}
\hline Year & $\begin{array}{c}\text { Total } \\
\text { Volume }\end{array}$ & $\begin{array}{c}\text { Year-over-year } \\
\text { growth, } \%\end{array}$ & $\begin{array}{l}\text { Export } \\
\text { volume }\end{array}$ & $\begin{array}{c}\text { Year-over-year } \\
\text { growth, \% }\end{array}$ & $\begin{array}{l}\text { Import } \\
\text { Volume }\end{array}$ & $\begin{array}{c}\text { Year-over-year } \\
\text { growth, \% }\end{array}$ & $\begin{array}{l}\text { Share in the } \\
\text { province's import } \\
\text { and export, } \%\end{array}$ & $\begin{array}{l}\text { Share in } \\
\text { China's import } \\
\text { and export, \% }\end{array}$ \\
\hline 2008 & 110.6 & 3.1 & 79.7 & -2.5 & 30.9 & 20.9 & 48.3 & 19.5 \\
\hline 2009 & 55.8 & -49.6 & 32.7 & -59.0 & 23.1 & -25.4 & 34.4 & 14.4 \\
\hline 2010 & 74.7 & 34.0 & 42.8 & 31.1 & 31.9 & 38.1 & 29.3 & 13.5 \\
\hline 2011 & 189.9 & 154.0 & 43.5 & 1.5 & 146.4 & 360.0 & 49.3 & 24.0 \\
\hline 2012 & 213.1 & 12.2 & 51.6 & 18.6 & 161.5 & 10.4 & 56.3 & 24.2 \\
\hline 2013 & 223.6 & 5.8 & 69.1 & 34.0 & 154.5 & -3.3 & 57.1 & 21.8 \\
\hline 2014 & 232.6 & 4.1 & 89.3 & 29.2 & 143.5 & -7.1 & 56.9 & 18.9 \\
\hline 2015 & 108.5 & -53.4 & 20.8 & -76.7 & 87.7 & -38.9 & 51.7 & 15.9 \\
\hline 2016 & 91.9 & -15.3 & 17.0 & -27.7 & 74.9 & -11.9 & 55.6 & 13.2 \\
\hline 2017 & 110.9 & 22.5 & 16.3 & -2.6 & 94.6 & 28.2 & 58.1 & 13.1 \\
\hline 2018 & 181.9 & 64.7 & 11.2 & -29.5 & 170.7 & 80.4 & 69.8 & 17.3 \\
\hline
\end{tabular}

Source: [10; 11] and http://www.customs.gov.cn/tabid/2433/InfoID/877451/frtid/49629/settingmoduleid/126763/Default. aspx; http://bbs1.people.com.cn/post/129/1/2/170867642.html

\section{Eastern Silk Road Belt}

The main objectives pursued by the Eastern Silk Road Belt project were to build a cross-border transportation system for the Harbin-Russia-Europe Railway, to increase the interconnectedness of the infrastructure, to construct the supporting service facilities, to increase energy resource cooperation, and to accelerate the construction of cross-border industrial parks and industrial chains [12]. This, in turn, was expected to attract domestic and foreign industries to the region.

The project was implemented in 2014, and the province pursued its "opening-up" strategy: its total investment in Russian economy reached 1 billion US dollars, increasing by $20 \%$ in comparison with the previous period. Cooperation also involved the banking sphere: 10 commercial banks of the province established relationships with 24 commercial banks in Russia. The Harbin International Economic and Trade Fair was successfully upgraded to the "China-Russia Expo". The volume of the trade contracts signed at the first Expo amounted to 3.15 billion US dollars; 260 economic cooperation agreements were signed, involving 68.3 billion yuans. Harbin City was positioned as a center for cooperation with Russia $^{2} .13$ port areas were opened for cross-border tourism and the number of the border-crossing points issuing visas was increased to eight.

2 Retrieved from http://finance.sina.com.cn/china/ 20150129/095521426781.shtml
The preliminary work of the Sino-Russian crude oil pipeline II and Sino-Russian east-line natural gas pipelines was progressing smoothly. The Amur-Heihe border oil storage and transportation and refining and chemical complex project had been approved, and the Longxing Group and LongMay Group had started construction of six projects in Russia. The construction of the first cross-border Tongjiang Railway Bridge between China and Russia and the preliminary work on the Heihe Cross-Border Highway Bridge also advanced smoothly. The Harbin Airport opened three new routes to Russia. China-Europe trains that traveled directly to Warsaw, Poland, on average had 1.3 trains a day, with the entire journey lasting 13 days. The goods that were originally shipped to the Pearl River Delta via Dalian Port were now transported by rail to Vladivostok, saving nearly one week and reducing the costs by about $20 \%$. The volume of mixed passenger and cargo routes accounted for $40 \%$ of the total export volume of Russian e-commerce parcels. The actual utilization of foreign capital in the province exceeded 5 billion US dollars, with an increase by $11.1 \%$ [13].

As we said above, the construction of the Eastern Silk Road Belt is a part of the larger national Belt and Road Initiative. Within this project, Heilongjiang Province has built a new platform for undertaking domestic and foreign industrial transfer and constructed an export-oriented industrial system. 


\section{Longjiang Silk Road Belt}

In December 2014, the Economic Conference of Heilongjiang Provincial Party Committee clearly stated for the first time its intention to accelerate the construction of Longjiang Silk Road Belt connected to China-Mongolia-Russia Economic Corridor. Harbin is the centre of Longjiang Silk Road Belt, then the Belt goes eastwards via Suifenhe to Russia's Far East port of Vladivostok, which has transport connections with Japan, South Korea, and North Korea. In the southern direction, the Belt connects the province with East China and South China through the port of Dalian and then with the Bohai Sea, Yangtze River Delta and Pearl River Delta. In the west, the Belt is connected to Russia's city Chita and the Eurasian Continental Bridge via Manchuria. In the north, there is connection with the Russian Siberian Railway via Heihe and Mohe; the first two lines are connected to the Maritime Silk Road, and the latter two echo the Silk Road on the land (see Table 2).
Thus, Longjiang Silk Road Belt is aimed at building the most convenient and smooth international channel connecting Asia and Europe to boost export-oriented economy and enhance regional connectivity [14]. This way, Heilongjiang Province has the potential to attract new production enterprises, enhance its domestic and international industrial cooperation and thus create a new growth pole for the regional economy $[15 ; 16]$ (Table 3).

Since 2015, the Belt and Road Initiative, transcending time and space, has led Longjiang Province to actively plan to become a core area in the construction of the Longjiang Silk Road Belt of China-Mongolia-Russia Economic Corridor. The Longjiang Silk Road Belt follows the concept of "West to Europe, East to the Sea": cargo and passenger trains should be going straight to the hinterland of Europe, and the key role in creating the necessary channels would be played by the Harbin-Suifenhe-Russia land-sea transport channels.

Table 2

\section{Channel infrastructure layout}

\begin{tabular}{|c|c|}
\hline Channel & Layout \\
\hline $\begin{array}{l}\text { Land and Sea Trans- } \\
\text { port }\end{array}$ & $\begin{array}{l}\text { - by sea (ports): China's Guangzhou-Ningbo-Shanghai-South Korea's Busan-Japan's Niigata-Rus- } \\
\text { sian Far East's Vladivostok-Nakhodka-Dongfang; } \\
\text { - on land (railways): Suifenhe-Manchuria- Baikal-the Russian Siberian Railway and west to the } \\
\text { Baltic coast and the ports of Hamburg and Rotterdam }\end{array}$ \\
\hline Railway Transport & $\begin{array}{l}\text { Four main railway lines: } \\
\text { - Dalian Port-Tongjiang-the Russian Siberian Railway and Bea Railway; } \\
\text { - Russia Vladivostok's ports-Suifenhe - Manchuria-Russia's Siberian Railway connected to the } \\
\text { Hamburg and Rotterdam ports; } \\
\text { - Blabovichsk-the Siberian Railway and the Bea Railway; } \\
\text { - Laoheishan-Dongning-Suifenhe-Hulin-Raohe-Fuyuan-Tongjiang-Mingshan-Xunke-Heihe-Mohe } \\
\text { and other ports - the Siberian Railway and Bea Railway }\end{array}$ \\
\hline Highway Transport & $\begin{array}{l}\text { - local expressways in the Harbin metropolitan area; } \\
\text { - Suihua-Daqing, Harbin-Wuyuan, Shuangyashan-Baoqing, etc. } \\
\text { - first-class and second-class highways along the border roads (Mohe-Dongning); } \\
\text { - the boundary river bridges (Heihe-Dongning-Luogu River) }\end{array}$ \\
\hline Water Transport & $\begin{array}{l}\text { - Harbin Port and Jiamusi Port (hub); } \\
\text { - Heihe, Fuyuan and other ports (nodes); } \\
\text { - Tongjiang Port-Russia's Khabarovsk-Gongqingcheng-the Strait through the Heilongjiang River; } \\
\text { - Fuyuan Port-Qianfu Railway-the Yujita Gangyuan Economic Zon-Yujita Deepwater Port Area }\end{array}$ \\
\hline Aviation Transport & $\begin{array}{l}\text { - Harbin Taiping International Airport as the hub (China-Russia-Central Europe-North America); } \\
\text { - regional airports as the nodes (Qiqihar, Mudanjiang, Jiamusi, Heihe, Mohe, Fuyuan and others); } \\
\text { - Sino-Russian cargo charter flights (Harbin Airport- Russia's Yekaterinburg Airport) }\end{array}$ \\
\hline Pipeline Transport & $\begin{array}{l}\text { - Sino-Russian Mohe-Daqing oil transport pipeline; } \\
\text { - the Sino-Russian eastern natural gas transport pipeline from the Heihe River; } \\
\text { - the second-line project of Sino-Russian crude oil pipeline; } \\
\text { - the Mohe-Daqing double line; } \\
\text { - the Sino-Russian East Line natural gas pipeline project }\end{array}$ \\
\hline Grid Transmission & $\begin{array}{l}\text { - the cross-border international transmission line in Heihe, the Sino-Russian border and the trans- } \\
\text { mission line of Harbin-Tangshan }\end{array}$ \\
\hline $\begin{array}{l}\text { Cable Communica- } \\
\text { tion }\end{array}$ & $\begin{array}{l}\text { - the International Communication Gateway Bureau in Harbin; } \\
\text { - the Arctic Circle Europe-Asian optical cable communication backbone network (Russia's Mur- } \\
\text { mansk-along the Arctic Ocean-through the Bering Strait from Vladivostok-via the Suifenhe River } \\
\text { and Harbin) }\end{array}$ \\
\hline
\end{tabular}


Table 3

Industrial layout planning

\begin{tabular}{|l|l|}
\hline \multicolumn{1}{|c|}{ Industrial layout } & \multicolumn{1}{c|}{ Specific planning } \\
\hline One core & $\begin{array}{l}\text { Harbin as the core hub performs the following functions: } \\
\text { - a Sino-Russian economic and trade cooperation platform, a cooperative enterprise headquar- } \\
\text { ters, a logistics hub, manufacturing bases, information finance services, cultural science and } \\
\text { technology exchange centers }\end{array}$ \\
\hline Four belts & $\begin{array}{l}\text { Four industrial belts with advanced technologies, distinctive characteristics and strong compet- } \\
\text { itive advantages: } \\
\text { - Harbin-Daqing-Qiqihaer-Manchuria; } \\
\text { - Harbin-Mudanjiang-Suifenhe-Dongning; } \\
\text { - Harbin-Jiamusi-Suifenhe-Dongning; } \\
\text { - Harbin-Suifenhe-Beian-Heihe }\end{array}$ \\
\hline One ring & $\begin{array}{l}\text { The ring is aimed at development of export-oriented economy with the border towns as nodes } \\
\text { (Mohe, Sunwu, Xunke, Jiayin, Luobei, Tongjiang, Fuyuan, Raohe, Hulin and Mishan) }\end{array}$ \\
\hline $\begin{array}{l}\text { Domestic and cross-bor- } \\
\text { der cooperation }\end{array}$ & $\begin{array}{l}\text { - overseas industrial parks; } \\
- \text { cooperation between the provincial enterprises and the foreign-funded enterprises; } \\
- \text { six cross-border industrial clusters }\end{array}$ \\
\hline
\end{tabular}

Recently, Heilongjiang Province has become increasingly prominent as a core hub for trade and exchange between countries in Northeast Asia. The Harbin Comprehensive Bonded Zone was officially launched and the railway container center station was put into use. Harbin Airport's dominance of Russian e-commerce cargo has been established, and Wudalianchi Airport and Jiansanjiang Airport have been opened successively. The China-Russia Expo attracts guests from nearly 100 countries and regions. The construction of the Sino-Russian Tongjiang Railway Bridge project, the construction of the Sino-Russian Heihe Highway Bridge, and the construction of the Bear Island Highway Passenger Port have been actively promoted. The Harbin-Mudanjiang and Harbin-Jiamusi Express Railways are about to be completed. The second-line project of the Sino-Russian crude oil pipeline was approved by the National Development and Reform Commission, and the Sino-Russian East-line natural gas pipeline Heihe domestic control project was implemented by more than a half.

Following the successful realization of the two above-described projects, in April 2017, Heilongjiang Province proposed another project "One Window and Four Districts", which is aimed at opening yet another window between China and the North and includes construction of the Sino-Russian Free Trade Area [17].

\section{Conclusion}

The Belt and Road Initiative is a major strategic decision made by the Party's Central
Committee and the State Council to meet global challenges, to create a new pattern of China's opening-up to the West, and to promote world peace and development. In the past five years, Heilongjiang Province has joined the national Belt and Road project and participated in the construction of China-Mongolia-Russia Economic Corridor. The main strategic priorities pursued by the province's government are to boost the connectivity of infrastructure, finance, trade, and people and to foster industrial cross-border cooperation.

After a dramatic decline in trade with Russia in 2016, the situation has started to improve in the following years as both sides were actively cooperating in the spheres of channel construction and cargo transportation, although the problems inherent in the cooperation with Russia have not been fully resolved yet. We believe that the following measures would contribute to further development of economic and trade cooperation between the province and Russia [18]: modernization of trade, that is, building a cross-border e-commerce base; fostering cooperation in the industrial sphere by building a cross-border industrial base; using the Belt and Road Initiative to connect with the Eurasian Economic Union for large-scale cooperation; using the advantages of agricultural resources in the Russian Far East to create a green food processing base; and, finally, using the opportunity of the Russian Far East Development Strategy to launch negotiations about establishing a Sino-Russian free trade zone. 


\section{References}

1. Songlinlin (2018). Research on the Strategic Upgrade of Heilongjiang Province's Cooperation with other Countries in Northeast Asia. Northeast Asia Economic Research, 6, 35-42.

2. Sui Yan. (2016). Historic background of Eastern Land-sea Silk Road Economic Belt from the Perspective of the Belt and Road. Heilongjiang History, 12, 3-7.

3. Xi Jinping (2018). Sharing New Opportunities in the Development of the Far East and Creating a Bright Future for Northeast Asia, Xinhua.net.com, 9. Retrieved from http://www.sohu. com/a/253726895 99911772

4. Heilongjiang Provincial Government. (2018). Work Report. Heilongjiang Daily, 1. Retrieved from http://district.ce.cn/newarea/roll/201801/31/t20180131 27986317 2.shtml

5. Heilongjiang Provincial Government. (2017). The $12^{\text {th }}$ Party Congress of Heilongjiang Province, 4. Retrieved from http://www.hljmzt.gov.cn/915/24477.html

6. Heilongjiang Provincial Government. (2018). Zhang Qingwei's Speech on In-depth Study and Implementation of Spirit of General Secretary Jin Ping's speech in Heilongjiang. Heilongjiang Daily, 5. Retrieved from http://cpc.people.com.cn/n1/2018/0528/c64102-30017715.html

7. Liu Shuang (2018). Heilongjiang Province's Opening-up and Development in a New Era, Heilongjiang Daily, 1.

8. Zhang Qingwei (2017). Deploying Heilongjiang Provincial Participation in the Belt and Road, Building "One Window, Four Districts", Heilongjiang Daily, 8.

9. Wang Xin (2018). Research on the Influencing Factors and Countermeasures of Heilongjiang Province's Economic and Trade Cooperation with Russia. Master's thesis of Harbin University of Commerce, 6, 9-10.

10. Zhao Ying, Zhengrui (2018). Reinvigorating Heilongjiang Province's Border Trade with Russia. Business and Economy, 3, 22-24.

11. Zou Xiuting (2018). Research on the Development of Economic and Trade Cooperation between Heilongjiang Province and Russia in the Background of China-Mongolia-Russia Economic Corridor. Siberian Studies, 2, 5-8.

12. Heilongjiang Province (2014). The Work Plan for Promoting the Eastern Land-sea Silk Road Economic Belt, 11. Retrieved from http://www.doc88.com/p-9572114008444.html

13. Heilongjiang Bureau of Statistics. (2014). Statistical Communique of the National Economic and Social Development of Heilongjiang Province, 3. Retrieved from http://district.ce.cn/zt/zlk/ bg/201601/13/t20160113_8257109_1.shtml

14. Zhang Xiaolian (2015). Implementing the Belt and Road Strategy and Promoting the Construction of Longjiang Silk Road Belt. Study and Exploration, 11. 1-3.

15. Da zhigang (2015). Suggestions on Promoting the Construction of Longjiang Silk Road, Heilongjiang Daily, 5.

16. Song linlin (2017). Analyses of the Current Situation of Promoting Longjiang Silk Road Belt, Cognition and Practice, 6, 104-108.

17. Zhang qingwei (2017). Deploying Heilongjiang Provincial Participation in the Belt and Road, Building One Window and Four Districts, Heilongjiang Daily, 8.

18. Ma Youjun (2018). Research on the Countermeasures of Promoting Cooperation with Russia in Heilongjiang Province under the New Normal. Business Economy, 7, 1-5.

\section{Author}

Song Linlin - Associate Researcher, Institute of Northeast Asian Studies, Heilongjiang Provincial Academy of Social Sciences (150028 No. 1000 Shibo Road Songbei District, Harbin, China); e-mail: songlinlin713@163.com

ARTICLE INFO: received October 5, 2018; accepted February 13, 2019

\section{Информация об авторе}

Линьлинь Сонг - младший научный сотрудник, Институт исследований СевероВосточной Азии, Провинциальная академия общественных наук провинции Хэйлунцзян (150028 No. 1000 Shibo Road, район Сунбэй, Харбин, Китай); e-mail: songlinlin713@163.com

ИНФОРМАЦИЯ О СТАТЬЕ: дата поступления 5 октября 2018 г.; дата принятия к печати 13 февраля 2019 г. 